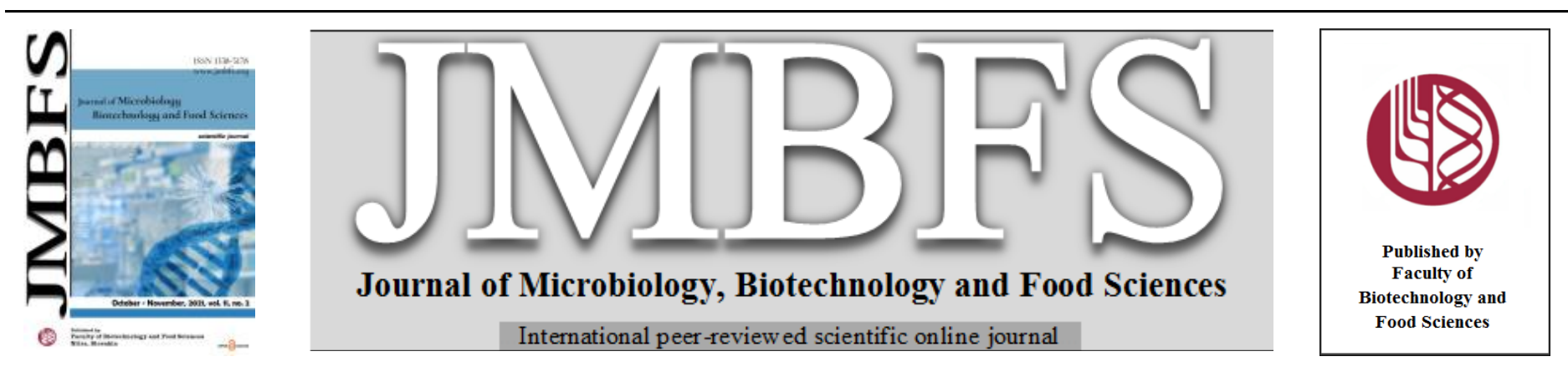

\title{
EFFECT OF SOYMILK SUBSTITUTION ON THE QUALITY PROPERTIES OF MALTED MAIZE BEVERAGE DRINK
}

\section{Ogori, Akama Friday ${ }^{2}$, Amove Julius ${ }^{2}$, Lyudmila Tretyak ${ }^{3}$, Nadezhda Kenijz ${ }^{4}$, Ivan Mikolaychik ${ }^{5}$, Larisa Morozova ${ }^{5}$, Lukas Hleba ${ }^{6}$, Mohammad Ali Shariati ${ }^{7}$}

\author{
$\operatorname{Address}(e s)$ : \\ ${ }^{1}$ Department of Home Science and Management, Faculty of Agriculture, Federal University, Gashua ,Nigeria. \\ ${ }^{2}$ Department of Food Science and Technology, Federal University of Agriculture, Makurdi, Benue State, Nigeria. \\ ${ }^{3}$ Department of Metrology, Standardization and Certification, Orenburg State University, 13 Pobedy Avenue, Orenburg, 460018, Russian Federation. \\ ${ }^{4}$ Department of Technology of Storage and Processing of Livestock Products, Kuban State Agrarian University, 13 Kalinina Str., 350044 , Krasnodar, Russian \\ Federation. \\ ${ }^{5}$ Kurgan State Agricultural Academy by T.S. Maltsev, Lesnikovo village, Ketovsky district, Kurgan region, 641300, Russian Federation. \\ ${ }^{6}$ Department of Microbiology, Faculty of Biotechnology and Food Sciences, Tr. A. Hlinku 2, Slovak University of Agriculture in Nitra, Slovak Republic. \\ ${ }^{7}$ K.G. Razumovsky Moscow State University of technologies and management (The First Cossack University), 73, Zemlyanoy Val St., Moscow, 109004, Russian \\ Federation.
}

*Corresponding author: ogorifaraday@gmail.com

https://doi.org/10.15414/jmbfs.4844

ARTICLE INFO

Received 13. 10. 2020

Revised 19. 5. 2021

Accepted 25. 5. 2021

Published 1. 10. 2021

Regular article

open $\bigodot_{\text {access }}$

\begin{abstract}
The effects of substituting soy milk with a malted yellow corn-based beverage were evaluated. The mixture of soy milk and malted yellow corn was formulated. $100 \%$ soy milk, $0 \%$ malted yellow corn as sample A, $90 \%$ soy milk, $10 \%$ malted yellow corn as sample B, $80 \%$ soy milk, $20 \%$ malted yellow corn as sample C, $70 \%$ soy milk, $30 \%$ malted yellow corn as sample D, and $60 \%$ soy milk, $40 \%$ malted yellow corn as sample E. The blends were evaluated for proximal, functional, microbial, and sensory attributes and compared with the control made from $100 \%$ soy milk using standard methods. The proximal composition of the blend showed that the moisture content of the blended beverage ranged from (80-85.8) \%, protein from (3.80-4.28) \%, ash content from (1.15-1.80) \%, crude fat from $(1.63-2.93) \%$, and carbohydrate from (2.48-13.01) \%. Total titratable acidity ranged from (0.030-0.65). The viscosity of the slurry beverage mixture ranged from 1.75 to 11.00 . PH values ranged from 5.0 to 9.66 . The microbial load ranged from (3.36x104- 5.33x106). For total fungi, sample B has the highest fungal count. There is no significant difference $(\mathrm{p}<0.05)$ in the number of fungi in all samples. Similarly, significant differences $(\mathrm{p}<0.05)$ existed in the sensory scores of flavor/aroma, texture, taste, and overall acceptability, except $(p<0.05)$ for appearance. All samples were generally acceptable in terms of sensory quality. Malted corn-based beverage replaced with soy milk could be used to alleviate hidden hunger, especially in rural communities.
\end{abstract}

Keywords: Soymilk, substitution, malted maize, beverages, drink, quality

\section{INTRODUCTION}

Soybeans are valued for their many qualities. It plays an important role in agriculture, trade and nutrition. It is an excellent source of protein, which is why the seed is the richest in nutritional value of all plant foods consumed in the world. It is used in fresh, fermented or dried form as flour, oil and condiment and for enrichment or fortification. It is rich in protein, calcium, phosphorus, iron and vitamins (Ahsan et al., 2020, 2021). Soy is the only vegetable source that contains all the essential amino acids. However, it is a poor source of vitamin C. Soybeans contain certain biologically active substances, called anti-nutritional factors, such as lecithin, trypsin, inhibitor, phytic acid, goitrogen and urea, which are water-soluble and heat-labile and therefore destroyed during processing. The hull is used as animal feed, while the meal can be used to enrich other foods and the residue can be used to make soups. Soy milk is a beverage made from soybeans. A traditional staple of Asian cuisine, it is a stable emulsion of oil, water and protein. Plain soy milk is unsweetened, although some soy milk products are sweetened. Salted soy milk is also consumed in China (William and Akiko, 2000).

The proteins are rich in lysine but poor in methionine (Pamplona-Roger and George, 2007). Fortification of soy milk with other nutrients found in corn and millet can be used to correct nutrient deficiencies in the products (Marero et al., 1989). There was an increase in lysine, tryptophan, and methionine in sprouted corn compared to unsprouted grain, as well as a reduction in viscosity. The consumption of grain-based food products from maize and millet is very common and popular worldwide, especially in developing African countries where they are a major source of their staple foods (Gernah et al., 2011). With total world cereal production estimated at 784 million tons in 2007 , these crops, particularly maize and millet, are widely grown and produced in significant quantities per year in most developing African countries (FAOSTAT, 2005).

Maize grains are rich in carbohydrates and also contain significant amounts of beta-carotene (Ingbian and Oduyela, 2010). Due to the unfavorable economic conditions prevailing in most developing countries of the world, especially in Nigeria where over $40 \%$ of the population lives below the poverty line (Nzeagwu and Nwaeijike, 2008). The incidence of protein-energy malnutrition in different age groups, especially among children, is widespread and increasing daily (Orji, 1994; Oosthuizen et al., 2006; Agiriga and Iwe, 2008).

This can be attributed to the fact that the ever-increasing population feeds mainly on their staple food crops (maize, millet, soybean, cassava) which have been reported to be poor sources of protein (FAO, 1995; Labadarious et al., 2005). This is not the case for protein sources, especially in terms of amino acid balance, but for carbohydrate-rich sources, especially starch. However, empirical evidence has shown that there is a strong positive relationship between good nutrition and the mental, physical and cognitive development of children in general, as wellnourished children are strong and healthy, have increased intellectual capacity and high school performance with reduced mortality and disease (Chandhari, 2008). Malting has proven to be one of the most effective and practical ways to improve the nutritional value of cereals (Adeyemo et al., 1992; Gernah et al., 2011).

In addition, there is a growing interest in formulating food products using the combination of composite mixtures of malted cereals and legumes as a means to improve the nutritional quality of products suitable for children (Agu and Aluya, 2004). The processing of cereals and legumes (through malting) and the formulation of intermediate products into nutritious mixtures that complement each other, especially in terms of essential amino acids, have been reported by 
several authors (Alabi and Anounye, 2007). Similarly, the use of legume meal to improve the protein quality of cereal and tuber meal in different food formulations has been studied and reported by various researchers (Iwe, 2001; Nnam, 2003; Agiriga and Iwe, 2008).

These studies have focused on the production of fortified breakfast meals, cookies and soft drinks. The consumption of cereal-based drinks across all age groups is very common in Nigeria and some West African countries for its thirstquenching and satiating properties (El-Mahmood and Doughari, 2007) However, the need to formulate and develop a high protein and energy drink for school children cannot be overemphasized as it is hoped that it will help to alleviate the endemic problem of protein energy malnutrition among schoo children, since most processed and packaged drinks available in Nigeria canno be classified as high protein and energy products. In addition, efforts in developing countries have been directed towards improving the quality of protein foods by using mixtures of legumes and cereals to form a more nutritionally balanced product in which this work fits

\section{MATERIALS AND METHODS}

\section{Materials}

The soybean, yellow maize and millet varieties used in this study were obtained from Wurukum market in Benue State. Other materials used were dried net, plastic bowl, pot, hammer mill, roller mill, sieve, gas stove, granulated sugar and food flavoring obtained from Makurdi modern market and drinking water was obtained from Makurdi University of Agriculture.

\section{Methods}

\section{Malting of yellow corn}

Using the modified method of (Osho, 1991), the grain was cleaned manually to remove stones and dirt. Cereals were washed in $5 \%(w / v)$ sodium chloride $(\mathrm{NaCl})$ solution to suppress mold growth and then soaked in portable water at room temperature $(30+20 \mathrm{C})$ at a ratio of $1: 3(\mathrm{w} / \mathrm{v})$ grains/water in a plastic container. The water was changed every 3 hours (to prevent fermentation) for a total period of 9 hours, after which the grains were drained and subjected to a 48 hour malting period. After 48 hours of germination, germination was stopped by drying in the cabinet dryer at $450 \mathrm{C}$ for 24 hours and then manually uprooted before being dry milled into flour using the Apex hammer mill (Model No: 114 S2/FLP) to obtain the corn and millet malt flour. Malt extraction from the malted grains was performed by adding 2.5 liters of water at $42-450 \mathrm{C}$ to $1 \mathrm{~kg}$ of each malt flour with stirring for 20-30 minutes for each malt flour produced in this study. The extract was obtained after decanting the surface water.

\section{Product mixture}

The product formulation used in this study is shown in Table 1 . The milk obtained from samples B, C, D, and E was mixed with sample A (soy milk) in a bowl. The mixture was sieved, boiled (10-20 minutes) to prepare a paste (which was continuously stirred to avoid lumps) from the milk. Added food flavouring $(0.25 \mathrm{~g})$ and table sugar $(50 \mathrm{~g})$ were incorporated into the mixtures to improve the organoleptic qualities of the developed beverages which are referred to as soy milk malt in this study. Finally, the mixture was allowed to cool for a few minutes and filled into a bottle.

Table 1 Blends Formulation of Soymilk and Malted Yellow Maize for Beverage Drink

\begin{tabular}{lccc}
\hline sample & Soymilk & $\begin{array}{c}\text { Malted yellow } \\
\text { maize }\end{array}$ & Blend composition \\
\hline A & 100 & 0 & $100 \%: 0 \%$ \\
B & 90 & 10 & $90 \%: 10 \%$ \\
C & 80 & 20 & $80 \%: 20 \%$ \\
D & 70 & 30 & $70 \%: 30 \%$ \\
E & 60 & 40 & $60 \%: 40 \%$ \\
\hline
\end{tabular}

Keys;

A $=100 \%$ Soy milk: $0 \%$ malted yellow maize

$\mathrm{B}=90 \%$ Soy milk: $10 \%$ malted yellow maize

$\mathrm{C}=80 \%$ Soy milk: $20 \%$ malted yellow maize

$\mathrm{D}=70 \%$ Soy milk:30\% malted yellow maize

$\mathrm{E}=60 \%$ Soy milk: $40 \%$ malted yellow maize

\section{Production of soybean milk}

Soybean was produced using the modified method of (Giesinde et al., 2008) with small modifications. Healthy soybeans obtained from Wurukum market in Makurdi were cleaned to remove stones, dirt and washed. The soybeans were then pressure cooked with $0.1 \%$ sodium bicarbonate for 15 minutes, drained, manually depelleted, and then wet milled (1000 g cooked soybeans to $250 \mathrm{ml}$ water) to a paste using a heavy duty blender (Waring blender, model CB15, serial number 556973). The milk was then extracted from the paste by filtration through a muslin cloth using one-part paste to four parts water. Figure 1 below shows the flow chart for the production of soy milk.

\section{Protein determination}

Two grams of yellow malted corn milk and nutsedge were measured into a Kjedhal digestion tube and $15 \mathrm{ml}$ of tetraoxosulfate (IV) acid (conc.H2SO4) was added for rapid dissolution. Kjedhal catalyst was added to accelerate the process which then yields a clear solution. Distilled water $(75 \mathrm{ml})$ was added to the tube after digestion, the mixture was distilled to $50 \mathrm{ml}$ using dilute $40 \% \mathrm{NaOH}$ solution and then into $25 \mathrm{ml}$ of $40 \%$ boric acid. The mixture was titrated with $0.47 \mathrm{M} \mathrm{HCl}$ to the first gray color. A blank titer was titrated and the value was recorded (AOAC, 2012).

$$
\% \text { Total Nitrogen }=\frac{\text { Titre value } \times 14.01 \times 0.47}{\text { Weight of sample } \times 100}
$$

$\%$ Protein $=$ Total nitrogen $\times$ conversion factor

Molecular weight of Nitrogen $=14.01$

Molarity of $\mathrm{HCl}=0.47$

Conversion factor $=6.25 \mathrm{xN}$

\section{Ash Content}

Two gramms ( $2 \mathrm{~g})$ of beverage blend samples was measured into an empty porcelain ignitable crucible that was ignited, cooled and measured. The sample was ignited over a hot plate in a fume cupboard to char organic matter. The ignitable crucible was placed in the muffle furnace maintained at $600^{\circ} \mathrm{C}$ for $6 \mathrm{hr}$ After ash, it was then cool in a desiccator and measured (AOAC, 2012).

\section{Ash}

$=\frac{(\text { Weight of the crucible }+ \text { Ash })-(\text { Weight of empty crucible }) \times 100}{\text { Weight of sample }}$

\section{Crude Fat}

The method of the AOAC. (2012) was used. The empty soxhlet die was measured as W1. Five (5) grams of dried sample was then added and measured as (W2). The soxhlet bottom flask was cleaned and measured empty as (W3), then filled with petroleum ether to three quarters of the flask. The Soxhlet extractor was attached with a condenser to adjust the heat sources so that the solvent boiled gently. The thermowell containing the sample solution was then placed in the Soxhlet apparatus and the extraction was performed for 6 hours. At the end, the vial containing the oil was dried in a hot air oven for one hour at $100^{\circ} \mathrm{C}$ to remove traces of water and solvent. Then it was cooled and weighed as (W4)

$$
\text { Percentage Fat content }=\frac{\mathrm{W} 4-\mathrm{W} 3}{\mathrm{~W} 2-\mathrm{W} 1} \times 100
$$

$\mathrm{W}_{1}=$ Empty thimble

$\mathrm{W}_{2}=$ Thimble and sample before extraction

$\mathrm{W}_{3}=$ Empty round bottom flask

$\mathrm{W}_{4}=$ Flask and extracted oil

\section{Crude fiber determination}

Crude fiber content was analyzed using the AOAC (2012). Two (2) grams of beverage sample was measured and placed in a $250 \mathrm{ml}$ beaker. The mixture was boiled for 30 minutes with 100 milliters of $\mathrm{H} 2 \mathrm{SO} 4$ at a molar concentration of 0.12 and then filtered. The filtrate was washed with boiled water until no acidic traces were detected. This procedure was performed twice and filtered with hot water and methylated spirits three times. The residue was transferred to a flammable crucible and dried in the oven at $1030 \mathrm{C}$ for $1 \mathrm{H}$. The crucible with its contents was cooled in a desiccator and then weighed as (W1). The residue was then introduced into an oven to be ashed at $600 \mathrm{C}$ for $1 \mathrm{H}$. The ashed sample was removed from the furnace and placed in a desiccator to cool and measured as (W2).

$$
\text { Crude Fiber }=W 1-W 2
$$

Where:

$\mathrm{W}_{1}=$ crucible and residue, $\mathrm{W}_{2}=$ final ash sample

\section{Carbohydrate content determination}

The carbohydrate content of each of the samples was obtained by difference according to (Ihekoronye and Ngoddy, 1985). That is, the difference between the total summation of percentage moisture, fat, ash, crude fibre, crude protein from $100 \mathrm{~g}$. 
$\%$ Carbohydrate $=100-($ Moisture + Protein + Fat + Ash + Fibre $) \%$

\section{Functional Properties}

\section{pH Measurement}

A $10 \% \mathrm{w} / \mathrm{v}$ suspension of each sample in distilled water was prepared. The suspension was mixed thoroughly with a stirrer and the $\mathrm{pH}$ measured with a digital $\mathrm{pH}$ meter.

\section{Viscosity}

The apparent viscosity of the slurries was determined using the method described by [7]. The samples were dissolved in $200 \mathrm{ml}$ of distilled water on a $5.0 \%$ (W/V) basis and allowed to remain at room temperature with constant agitation for one hour. Viscosity was the $\mathrm{n}$ measured using a viscometer.

\section{Total Acidity}

The total acidity was determined according to AOAC (2012), official method by direct titration of $2 \mathrm{~g} \quad \mathrm{o}$ the puree with $0.1 \mathrm{~m}$ sodium hydroxide using phenolphthalein as indicator. The total acidity (as \% citric acid) was calculated as follows:

Citric acid \% = Mole of $\mathrm{NaoH}$ x Vol. of (Base) x Mole Mass (acid) x 100 Milliequivalent of acid $\mathrm{x}$ volume of sample

\section{Total solid determination (Ts)}

Total solid was determined grammatically using the method by (Chandhari 2008). A measured weight of each test sample was put in a previously weighted evaporating dish and evaporated to dryness over a steam bath. It was then dried in an oven at $105^{\circ} \mathrm{C}$ for an hour. It was cooled in desiccators and then reweighted by difference, and the dry weight of the sample was obtained and expressed as percentage of the sample weight. The formula below used in detecting the total solid and subsequence the moisture content.

$$
\% \mathrm{Ts}=\frac{W_{2}-W_{1}}{\mathrm{~W}}
$$

Where: $\quad$ w=Weight of sample analysed $(\mathrm{mg})$

$\mathrm{W} 1=$ Weight of sample evaporating dish

$\mathrm{W} 2=$ Weight of dish + dry sample

Subsequently, $\%$ moisture content $=100$ - total solid

\section{Microbiological analysis}

\section{Determination of yeasts, moulds and bacteria}

Sample preparation by serial dilution: MaConky bottles were sterilized, arranged and labelled 10-1 appropriately. $9.0 \mathrm{ml}$ of peptone water was poured into the bottles. $1 \mathrm{ml}$ of the samples was taken from the first bottle and transferred to another bottle containing peptone water and labelled. Using another pipette, the contents of the first dilution were taken and transferred to the second bottle and labelled 10-2, this was repeated four times.

Preparation of media for total plate count: $28 \mathrm{~g}$ of nutrient agar powder was weighed and added to deionized water in a volumetric flask to 1 liter and mixed. The whole was heated gently to boiling and then sterilized in the autoclave at $15 \mathrm{psi}$ at 121 degrees centigrade for 15 minutes.

Preparation of media for molds and yeasts: Sabourand dextrose ager was prepared for the determination of molds and yeasts. $62 \mathrm{~g}$ of Sabourand dextrose ager was suspended in 1 liter of deionized water and soaked for 10 minutes in a volumetric flask, mixed and sterilized by autoclaving for 15 minutes at 121 degrees centigrade, cooled to 47 degrees centigrade.

\section{Determination of total plate count}

$1 \mathrm{ml}$ of the prepared samples was poured into a dish, $15 \mathrm{ml}$ of solid anger medium was poured into a Petri dish and allowed to form a gel, this was done in duplicate. The plates were incubated at $370 \mathrm{C}$ for $24-48$ hours. Colonies were counted per plate using a manual magnifying glass as described by (Adegoke, 2004).

\section{Determination of moulds and yeasts}

$1 \mathrm{ml}$ of the prepared serial dilution was placed in a Petri dish and $15 \mathrm{ml}$ of sabourand dextrose agar was poured in and allowed to gel, then incubated at $370 \mathrm{C}$ for $24-48$ hours.

\section{Statistical analysis}

All data obtained were subjected to one-way analysis of variance (ANOVA), and Turkey's statistical test was used to separate the means. A probability of $\mathrm{P}<0.05$ was considered statistically significant (Ihekoronye and Ngoddy, 1985) Results and Discussion

\section{Proximal composition of the malted yellow corn soymilk beverage}

The data presented in Table 4 shows the chemical composition of the mixture of soy milk and malted yellow corn in different proportions. The water content ranges from 80.07 to $85.88 \%$; sample $\mathrm{B}(85.88)$ has the maximum water content, while sample E (80.07) has a lower water content. The protein content varies from 3.80 to $4.28 \%$, which shows that the mixing ratio used to produce the soy milk malt is better as it increases the protein content of the soy milk. It was also observed that the sample coded as B had the highest protein content, followed by sample C. The ash content of the soymilk blend samples varied from 1.15 to $1.80 \%$. There is no significant difference between the two products because they are in the same range. The fat content ranges from 1.63 to 2.93 in the soy milk sample, indicating that the product is high in fat. The carbohydrate value in the soy milk is significantly different, showing that the soy milk with a value of 2.48 has a lower carbohydrate value than the one that was mixed with malted yellow corn. The value of the samples ranges from 2.48 to 13.01 , with sample E having the maximum value. This indicates that mixing with malted corn increases the carbohydrate content of the soy milk.

Table 2 Proximate Composition of Beverage Drink from Soymilk and Malted Yellow maize

\begin{tabular}{lccccc}
\hline Sample & Moisture & Protein & Fat & Ash & Carbohydrate \\
\hline A & $85.00^{\mathrm{c}}$ & $3.80^{\mathrm{a}}$ & $2.93^{\mathrm{a}}$ & $1.30^{\mathrm{a}}$ & $2.48^{\mathrm{d}}$ \\
B & $85.88^{\mathrm{a}}$ & $4.28^{\mathrm{b}}$ & $2.66^{\mathrm{b}}$ & $1.25^{\mathrm{c}}$ & $5.80^{\mathrm{a}}$ \\
C & $80.34^{\mathrm{d}}$ & $4.13^{\mathrm{c}}$ & $2.03^{\mathrm{f}}$ & $1.15^{\mathrm{f}}$ & $8.28^{\mathrm{b}}$ \\
D & $75.00^{\mathrm{e}}$ & $4.04^{\mathrm{e}}$ & $2.15^{\mathrm{c}}$ & $1.79^{\mathrm{d}}$ & $11.48^{\mathrm{b}}$ \\
E & $80.50^{\mathrm{b}}$ & $3.81^{\mathrm{f}}$ & $1.63^{\mathrm{d}}$ & $1.80^{\mathrm{e}}$ & $13.01^{\mathrm{c}}$ \\
LSD & 0.005 & 0.005 & 0.005 & 0.005 & 0.005 \\
\hline
\end{tabular}

Means are values from two determinations. Means with different superscript within the same column are significantly different at $(\mathrm{p}>0.05)$

Keys

A $=100 \%$ Soy milk: $0 \%$ malted yellow maize

$\mathrm{B}=90 \%$ Soy milk: $10 \%$ malted yellow maize

$\mathrm{C}=80 \%$ Soy milk: $20 \%$ malted yellow maize

$\mathrm{D}=70 \%$ Soy milk: $30 \%$ malted yellow maize

$\mathrm{E}=60 \%$ Soy milk:40\% malted yellow maize

Table 3 Functional property of Beverage drink from soymilk and Malted Yellow Maize

\begin{tabular}{|c|c|c|c|c|}
\hline sample & Total solid & TTA & Viscosity & $\mathrm{pH}$ \\
\hline $\mathrm{A}$ & $15.00^{\mathrm{d}}+\_0.01$ & $0.030^{\mathrm{e}}+0.0001$ & $1.75^{\mathrm{e}}+0.007$ & $5.00^{\mathrm{d}}+\_0.01$ \\
\hline B & $14.12^{\mathrm{c}}+0_{0.1}$ & $0.049^{\mathrm{d}}+0.0002$ & $4.75^{\mathrm{a}}+0.007$ & $4.12^{\mathrm{c}}+{ }_{-0.01}$ \\
\hline $\mathrm{C}$ & $19.66^{\mathrm{a}}+0.15$ & $0.056^{\mathrm{c}}+\_0.0006$ & $7.00^{\mathrm{b}}+\_0.006$ & $9.66^{\mathrm{c}}+\_0.15$ \\
\hline $\mathrm{D}$ & $15.00^{\mathrm{b}}+{ }_{0} 0.1$ & $0.059^{\mathrm{a}}+{ }_{0} 0.0001$ & $9.00^{\mathrm{e}}+[0.06$ & $5.00^{\mathrm{b}}+{ }_{0} 0.01$ \\
\hline $\mathrm{E}$ & $19.50^{\mathrm{e}}+{ }_{0} 0.1$ & $0.065^{\mathrm{c}}+0.0002$ & $11.00^{\mathrm{d}}+\_0.006$ & $9.50^{\mathrm{e}}+\_0.01$ \\
\hline
\end{tabular}

Means are values from two determinations .Means with different superscript within the same column are significantly different at $(\mathrm{p}>0.05)$

Keys

$\mathrm{A}=100 \%$ Soy milk:0\% malted yellow maize

$\mathrm{B}=90 \%$ Soy milk: $10 \%$ malted yellow maize

$\mathrm{C}=80 \%$ Soy milk: $20 \%$ malted yellow maize

$\mathrm{D}=70 \%$ Soy milk:30\% malted yellow maize

$\mathrm{E}=60 \%$ Soy milk:40\% malted yellow maize

\section{Physical Properties of Beverage Drink from Soymilk and Malted Yellow maize}

The result shows that soluble solids are higher in control sample and sample A respectively, while samples $\mathrm{B}, \mathrm{C}, \mathrm{D}$ and $\mathrm{E}$ have almost the same percentage of soluble solids. The result of titratable acidity (\% lactic acid) in the soy milk sample presented in Table 3 revealed that high acidity can be an advantage in that better milk will be produced. High acidity promotes digestibility during the hydrolysis of lactose to lactic acid (Ohenhen and Ikenemoh, 2007). Their acidity value varies; the control is 0.03 . Sample $\mathrm{E}$ has the highest acidity value of 0.065 , while sample $\mathrm{A}$ has the lowest acidity value of 0.03 . This difference is a result of the blend ratio and the variety of corn used, meaning that malting increases the acidity values of the product. Steeping alone gives the product a high acidity value. The recommended standard is 0.6 (FDA, 1999).

The viscosity of the blend increases with increasing blend percentage. The control sample had the least viscous flow and the E sample with about $40 \%$ malt addition had the highest value. This observation may be from the concentration 
of solutes from the leaching of soluble amylose in the beverage. The $\mathrm{pH}$ of the soy milk sample and its mixture with malted yellow corn, the data reveal that the samples are slightly acidic (low acid foods) and range from 5.93 to 6.08, which is slightly above the average as indicated by (Olukoya, 1994). This acidity is slightly higher than the average acidity reported by (Olukoya, 1994), thus reducing microbiological growth.

\section{Microbial Composition of Beverage Drink from Soymilk and Malted Yellow} maize

The quality evaluation on the microbial composition is presented in Table 7 . Total viable count ranged from $3.34 \times 10^{4} \pm 6.1-5.33 \times 10^{6} \pm 0$ with significan differences $(\mathrm{p} \leq 0.05)$ among sample $\mathrm{C}, \mathrm{D}$ and $\mathrm{E}$ but there was no significan difference among sample $\mathrm{A}$ and $\mathrm{B}$. Total fungi count of the blend ranged from < $30-3.43 \times 10^{6} \pm 0$. There were no significant differences among all the samples.

Table 4 Microbial Loads of soymilk and malted yellow maize Beverage Drink

\begin{tabular}{|c|c|c|}
\hline Sample & Total Viable Count & Total Fungi Count \\
\hline A & $5.3 \times 10^{6}+6.0^{\mathrm{c}}$ & $1.1 \times 10^{6}+0_{0.0^{\mathrm{a}}}$ \\
\hline B & $4.2 \times 10^{5}+5.9^{\mathrm{b}}$ & $3.4 \times 10^{6}+{ }^{6} 0.0^{\mathrm{a}}$ \\
\hline $\mathrm{C}$ & $4.1 \times 10^{4}+{ }^{6} .1^{\mathrm{b}}$ & $3.0 \times 10^{2}+\underbrace{}_{1.4^{\mathrm{a}}}$ \\
\hline $\mathrm{D}$ & $3.4 \times 10^{4}+4.99^{\mathrm{b}}$ & $<30$ \\
\hline $\mathrm{E}$ & $3.3 \times 10^{4}+6.1^{\mathrm{a}}$ & $<30$ \\
\hline
\end{tabular}

Means are values from two determinations. Means are values from two determinations. Means with different superscript within the same column are significantly different at $(\mathrm{p}>0.05)$

Keys

$\mathrm{A}=100 \%$ Soy milk:0\% malted yellow maize

$\mathrm{B}=90 \%$ Soy milk: $10 \%$ malted yellow maize

$\mathrm{C}=80 \%$ Soy milk: $20 \%$ malted yellow maize

$\mathrm{D}=70 \%$ Soy milk:30\% malted yellow maize

$\mathrm{E}=60 \%$ Soy milk: $40 \%$ malted yellow maize

\section{Sensory attributed of beverage Drink Blends from Soymilk and Malted Yellow Maize}

The sensory attributes of the yellow malted tigernut and corn blend are presented in Table 5. The appearance of the blend ranged from 8.67 to 7.06 , with no significant difference between samples. Sample B had the highest score.

The flavor/aroma of the blend ranges from 7.12 to 8.01 with an LSD of 0.05 . There are no significant differences between samples A, B and D but there are significant differences $(\mathrm{p}<0.05)$ in samples $\mathrm{E}$ and C. Samples B and C have the highest scores of 8.01 and 8.0 and sample $E$ has the lowest scores of 7.80 in terms of flavor/aroma. The texture of the drink ranges from 5.96 to 7.90 with an LSD of 0.05. Samples A and B have similar values, with significant differences $(\mathrm{p}<0.05)$ in sample E. Sample C has the highest score of 7.90 and sample E has the lowest score of 5.96 in terms of texture. The taste of the mixture ranged from 8.00 to 5.00 with an LSD of 0.005 . There were no significant differences between samples A, B, C and D, but there were significant differences $(\mathrm{p}<0.05)$ in sample E. Sample A had the highest taste scores of 8.00 and sample E had the lowest taste scores of 5.00. Overall acceptability ranges from 8.30 to 6.09 with an LSD of 0.005 . There was no significant difference between the samples. The blend composed of $90 \%$ soy milk and $10 \%$ malted yellow corn had the highest score of 8.30 and the blend composed of $60 \%$ soy milk and $40 \%$ malted yellow corn had the lowest score of 6.09 for overall acceptability.

Table 5 Sensory Attribute of Blend of soymilk and malted yellow maize beverage drink

\begin{tabular}{llllll} 
Sample & Appearance & Flavor & Texture & Taste & $\begin{array}{l}\text { General } \\
\text { Acceptable }\end{array}$ \\
\hline A & $8.06^{\mathrm{c}}$ & $7.12^{\mathrm{d}}$ & $6.00^{\mathrm{b}}$ & $8.00^{\mathrm{f}}$ & $7.10^{\mathrm{a}}$ \\
$\mathrm{B}$ & $8.67^{\mathrm{a}}$ & $8.10^{\mathrm{b}}$ & $6.22^{\mathrm{d}}$ & $7.15^{\mathrm{c}}$ & $8.30^{\mathrm{r}}$ \\
$\mathrm{C}$ & $7.93^{\mathrm{b}}$ & $8.00^{\mathrm{a}}$ & $7.90^{\mathrm{c}}$ & $6.70^{\mathrm{a}}$ & $7.30^{\mathrm{f}}$ \\
$\mathrm{D}$ & $7.11^{\mathrm{c}}$ & $7.86^{\mathrm{f}}$ & $7.01^{\mathrm{b}}$ & $6.40^{\mathrm{b}}$ & $7.20^{\mathrm{c}}$ \\
E & $7.06^{\mathrm{e}}$ & $7.80^{\mathrm{a}}$ & $5.96^{\mathrm{f}}$ & $5.00^{\mathrm{e}}$ & $6.09^{\mathrm{d}}$ \\
LSD & 0.74 & 0.05 & 0.05 & 0.05 & 0.06 \\
\hline
\end{tabular}

Means are values from two determinations. Means with different superscript

within the same column are significantly different at $(\mathrm{p}>0.05)$

Keys

$\mathrm{A}=100 \%$ soy milk:0\% malted yellow maize

$\mathrm{B}=90 \%$ soy milk: $10 \%$ malted yellow maize

$\mathrm{C}=80 \%$ soy milk: $20 \%$ malted yellow maize

$\mathrm{D}=70 \%$ soy milk:30\% malted yellow maize

$\mathrm{E}=60 \%$ Soymilk: $40 \%$ malted yellow maize

\section{CONCLUSION}

The proximal compositions of the soy milk mixture with the malted yellow corn samples changed significantly as the proportion of malted corn increased relative to the control. The use of malted yellow corn and soy milk in different proportions has great potential. The beverage promoted all chemical, physical, and sensory attributes, resulting in increased reducing sugars and decreased bun elasticity. Therefore, it is recommended to check the content of micro and macro nutrients, vitamins, amino acids and fatty acids in this drink, as well as the bioavailability of proteins, digestibility and toxicity level of the drink

Conflict of interest: There are no conflicts of interest among the authors

\section{REFERENCES}

Adeyemo, S.O.,Olayed, O.B., \& Odutuga, A.A. (1992). Biochemical analysis of germinated white maize Zeamays. Nigeria Journal of Nutrition, 13,18-24

Agiriga, A.N., \& Iwe, M.O. (2008). Physical properties of cookies produced from cassava groundnut-corn starch blend. A Response Surface Analysis. Nigerian Food Journal, 26 (2), 83-95.

Agu, H.O., \& Aluya, O. (2004). Production and Chemical analysis of weaning food from maize, soybean and flued pumpkin sed flour. Nigerian Food Journal, 22, 171-177

Adeyemo, S.O., Olayed, O.B., \& Odutuga, A.A. (1992). Biochemical analysis of germinated white maize Zeamays. Nigeria Journal of Nutrition, 13,18-24 Agiriga, A.N., \& Iwe, M.O. (2008). Physical properties of cookies produced from cassava groundnut-corn starch blend. A Response Surface Analysis. Nigerian Food Journal, 26 (2), 83-95. https://doi.org/10.4314/nifoj.v26i2.47441

Agu, H.O., \& Aluya, O. (2004). Production and Chemical analysis of weaning food from maize, soybean and flued pumpkin sed flour. Nigerian Food Journal, 22(1), 171-177. https://doi.org/10.4314/nifoj.v22i1.33584

AOAC. (2012). Official methods of Analysis of Association of Official Analytical Chemistry International, 19th edition. Washington, DC.

Ahsan, S., Khaliq, A., Chughtai, M.F.J., Nadeem, M., Din, A.A., Hlebová, M., Rebezov, M., Khayrullin, M., Mikolaychik, I., Morozova, L., \& Shariati, M.A. (2020) Functional Exploration of Bioactive Moieties of Fermented and NonFermented Soy Milk with Reference to Nutritional Attributesax. Journal of Microbiology, Biotechnology and Food Sciences, 10 (1), 145-149.

Ahsan, S., Khaliq, A., Chughtai, M.F.J., Nadeem, M., Tahir, A.B., Din, A.A. Ntsefong, G.N., Shariati, M.A., Rebezov, M., Yessimbekov, Z., \& Thiruvengadam, M. (2021) Technofunctional quality assessment of soymilk fermented with Lactobacillus acidophilus and Lactobacillus casei. Biotechnology and Applied Biochemistry, PubMed: 33398897, DOI: 10.1002/bab.2094

Alabi, M.O., \& Anounye, J.C. (2007). Sensory and Nutritional attributes of soy supplemented cereal meals. Nigerian Food Journal, 25, 100110. https://doi.org/10.4314/nifoj.v25i1.33658.

Adegoke, G.O. (2004). Understanding Food Microbiology, 2nd Edition. AlleluianVentures, Ibadan, Nigeria. Pp. 216.

AOAC. (2005). In W. Horowtiz (Ed.) Official Methods of Analysis of the Association of Official Analytical Chemists, 17th Edition, Gaithersbudg MD.

Breadly Herbal Medical Assocaition (1989). British Herbal Pharmacopoeia 1983, British Herbal Medicine Association.

Chandhari, R. (2008). Developing Healthy food for kids. food marketing and Technology (April Edition).

El-Mahmood, A.M., \& Doughari J.H. (2007). Microbial quality assessment of kunu zakibeverage sold in girei town of adamawa state Nigeria. AFJS, 11-15.

FAO. (1995). Le sorgho et les mils dans la nutrition humaine. Collection FAO (Rome).

FDA. (1999). Percentage juice declaration 21 CFR, volume 11, part 101.30

FAO. (1992). Technology of production of edible flour and protein products from soybean FAO bulletin No97.

FAOSTAT. (2005). Food and Agricultural Commodities production statistics. Food and Agriculture Organization, Rome

Gernah DI, Ariahu CC, Ingbian EK (2011). Effect of malting and lactic fermentation on some chemical and function properties of maize (Zea mays). American Journal of Food Technology. 6 (5), 404-412. https://doi.org/10.3923/ajft.2011.404.412.

Giesinde, A.F., Oyawoye, O.M., Adebisi, A. (2008). Comparative studies on the quality and quantity of soymilk from different varieties of soybean. Pakistan Journal of Nutrition, 1, 157-160. https://doi.org/10.3923/pjn.2008.157.160.

Ingbian, E. K., \& Oduyela, G. S. (2010). Proximate composition and physical properties of selected maize grains varieties. Nigerian food Journal, 281, 151163. https://doi.org/10.4314/nifoj.v28i1.57424.

Ihekoronye, A.I., \& Ngoddy, P.O. (1985). Integrated Food Science and Technology for the Tropics. MacMillan Publishers, New York. pp 296-300.

Iwe, M.O. (2001). Proximate, physical and sensory properties of full fat soy flour and plantain flour cookies. Global Journal of Pure and Applied Sciences, 8 (2), 187-191. https://doi.org/10.4314/gjpas.v8i2.16030

Labadarious, D., Steyn, N.P., Maunder, E., Macintyre, V., Gericke, G., SwartRHuskosson, J., Danhausa, A., Vaserter, H.H., Nesmuuni, A.E., Nej, J.K (2005). The national food composition survey SA 1999. Public Health Nutrition, 8(5), 553-554. https://doi.org/10.1079/phn2005816.

Lui, A.H. (2000). Home preparation of soymilk. A new concept in whole soybean food for home and village use. Intsoyseries, 14, 5-9. 
Marero, L.M., Pagumo, E.M., Aguinaldo, A.R., \& Homma, S. (1989). Nutritional characteristic of weaning food prepared from germinated cereals and $\begin{array}{llll}\text { legumes. Journal of food } & \text { Science, 53(5), } 1399\end{array}$ 1402. https://doi.org/10.1111/j.1365-2621.1988.tb09286.x .

Nnam, N.M. (2003). Nutrient composition and sensory properties of snacks produce from blends of some Nigeria indigenous food crops. Nigeria Journal of Nutrition Science, 242, 52-57

Nzeagwu, O.C., \& Nwaeijike, N.J. (2008). Nutrient Composition, Functional and Organoleptic Properties of Complementary Foods Formulated From Sorghum, Groundnut and Crayfish. Nigerian Food Journal, 26 (1) https://doi.org/10.4314/nifoj.v26i1.47418.

Ohenhen, R.E., \& Ikenemoh, M.J. (2007). Shelf stability and enzyme activity studies of Ogi: A corn meal fermented product. Journal of America Science, 3(1), 38-42.

Olukoya, D. K., Ebugwei, S., Olasupo, N.A., \& Ogunjinmi, A. (1994) Production of Dogik: an improved Ogi (Nigerian fermented weaning food) with potentials for use in diarrhea control. Journal of Tropical Paediatrics, 40, 108114. https://doi.org/10.1093/tropej/40.2.108.

Orji, K.O. (1994). Comparative analysis of rural -urban demand for cassava products in Abia state.Msc thesis. Dept of Agricultural Extension. UNN. NJFS, 24(1), 139.

Oosthuizen, D., Napier, C., \& Oldewege- theron, W. (2006). The formulation and development of a multi-mix for primary school children within an informal, South Africa. Nigeria Journal of Science, $24 \quad$ (1), 149 https://doi.org/10.4314/nifoj.v24i1.33647.

Osho, S.M. (1991). Soybean as food in Nigeria. Training manual. A national worksop on soybean processing and utilization for women groups in Nigeria 20th - 24th May.

Pamplona -Roger, M.D., \& George, D. (2007). Health food printed in the European Union. Sanfernando de Henares, Madrid Spain.

William, S., \& Akiko, A. (2000). Tofu and soymilk production 3rd edition Lafayette, California: soyfood cntre ISBN 0-933332-72-6. 